\title{
Языковая политика Франции
}

\section{Бернар Серкильини}

DOI: 10.30547/mediaalmanah.6.2020.130133

(C) Серкильини Бернар председатель Научного комитета Словаря франкофонов (Париж, Франция)
Старейшим французским юридическим документом, действующим до сих пор, является «Ордонанс об отправлении правосудия», изданный Франциском I в августе 1539 г. в Виллер-Котре. Статья 111 этого королевского указа запрещает использование латыни в правосудии: языковая политика становится элементом формирования суверенитета. Во Франции язык - атрибут государства, а со времен Французской революции - и нации.

Языковая политика - это комплекс согласованных действий государства, имеющих целью защиту одного или нескольких языков. Франция относится к числу стран, проводивших такую политику постоянно.

Языковая политика имеет два аспекта:

-деятельность в области «языкового обустройства», воздействующая на природу языка: регулирование вариативности, определение языковой нормы, определение правил орфографии ит.д. Преобразование кардиналом Ришелье клуба писателей во Французскую академию - официальное учреждение, которое находится под защитой государства, имеет высокий статус и решает возложенную на него задачу «дать точные правила нашему языку», в частности в области орфографии, - является заслугой монархии. Можно также упомянуть о целенаправленной деятельности государства в эпоху генерала де Голля, когда решалась 


\section{La politique linguistique de la France}

Bernard Cerquiglini

(C) Cerquiglini Bernard

président du Comité scientifique du Dictionnaire des francophones

(Paris, France)

1. Le plus ancien texte juridique français toujours en vigueur est l'Ordonnance sur les faits de justice, prise par François ler, en août 1539, à Villers-Cotterêts. Son article 111 bannit l'usage du latin dans la Justice : la politique linguistique est constitutive de la souveraineté. La langue est en France un attribut de l'Etat et, depuis la Révolution française, de la Nation.

2. Une politique linguistique est un ensemble concerté d'actions publiques, explicitement attachées à la protection d'un ou plusieurs idiomes. La France est au nombre des pays mettant en œuvre depuis toujours une telle politique.

3. Une politique linguistique peut prendre deux aspects :

- Une politique d'aménagement, qui s'applique à la nature de la langue : choix d'une variété légitime, norme, graphie, etc. La transformation par Richelieu d'un club d'écrivains en une Académie françoise, institution officielle, protégée et célébrée, chargée de « donner des règles certaines à notre langue » notamment en matière d'orthographe, est à mettre au compte de la Monarchie. On peut citer de même l'action volontariste de l'Etat à l'époque du général de Gaulle. On entendait alors équiper la langue, comme on dotait le pays d'une indépendance énergétique et militaire : création d'un dispositif d'enrichissement de la langue (production terminologique), rédaction, à l'initiative du Président de Gaulle, par la recherche publique, d'un dictionnaire volumineux, le Trésor de la langue française.

- Une politique d'emploi, qui entend protéger, promouvoir ou imposer l'usage d'un idiome. Cette politique est en général contrastive. A la Renaissance, il s'agissait du latin (ordonnance de Villers-Cotterêts) et de l'italien. Plus tard, des langues régionales, envers lesquelles la République « indivisible » ne montra nulle tendresse. Il s'agit de nos jours de faire pièce à la langue anglo-américaine : inscription du français « langue de la République » dans la Constitution (25 juin 1992) ; loi relative à l'emploi de la langue dans le commerce, au travail, dans les médias, etc. (4 août 1996). Une telle politique peut être nationale : elle relève alors de l'exercice de la souveraineté. Elle peut avoir une dimension internationale, relevant de l'influence ; elle implique alors un partage de la souveraineté : ce partage définit la Francophonie.

4. Les impressionnants acquis de la politique linguistique française $n$ 'interdisent pas d'examiner les défis actuels qu'elle doit relever. 
задача укрепления языка, - точно так же, как решалась задача укрепления энергетической и военной независимости страны. Результатом этой деятельности стало создание механизма обогащения языка (за счет введения французских терминов) и составление, по инициативе Президента де Голля и благодаря осуществляемой государством исследовательской работе, многотомного словаря «Сокровище французского языка»;

-деятельность в области использования языка, цель которой состоит в том, чтобы продвигать (или предписывать) использование языка. Как правило, эта деятельность направлена на продвижение одного языка и одновременное ограничение использования другого. В эпоху Возрождения речь шла о противопоставлении французского языка латыни (ордонанс Виллер-Котре) и итальянскому языку. Позднее это были региональные языки, в отношении которых «неделимая» Республика не проявляла ни малейшей жалости. Сегодня речь идет об англо-американском языке: в связи с этим важными моментами стало закрепление в Конституции статуса французского языка как «языка Республики» (25 июня 1992 г.) и принятие закона об использовании французского языка в сфере торговли, на рабочем месте, в СМИ (4 августа 1996 г.). Эта политика носит национальный характер, поскольку относится к сфере суверенитета государства, и одновременно имеет международное измерение, связанное с влиянием языка в мире: в этом смысле она предполагает, что государство делится своим суверенитетом с другими странами, - именно это и определяет сущность франкофонии.

Языковая политика Франции, несмотря на достигнутые результаты, должна ответить на определенные вызовы:

-деятельность по «языковому обустройству», которая ранее осуществлялась
Академией на основе языкового разнообразия, наблюдавшегося в самой Франции, в настоящее время сталкивается с проблемой международного распространения французского языка. Сегодня необходимо официально признать обусловленные этим обстоятельством вариативность и множественный характер нормы, измерить богатство этого многообразия. В этом смысле подготовка - по инициативе Президента Эммануэля Макрона - электронного «Словаря франкофонов», который разрабатывается благодаря партнерскому взаимодействию франкофонов различных стран и призван отразить лексическое многообразие французского языка в том виде, в каком он существует в мире, представляет собой современную форму традиционной деятельности государства, направленной на продвижение языка и осуществляемой в рамках новых теоретических подходов;

-деятельность по защите использования языка на протяжении длительного времени касалась исключительно государственного языка. Требования регионов, позиция других стран Европейского союза, учет нематериального и речевого наследия приводят Францию к необходимости переосмыслить свою деятельность с целью поддержки региональных языков и языков меньшинств. В этом смысле создание Национального управления по продвижению французского языка и языков Франции, первого органа, призванного осуществлять глобальную языковую политику, является современным административным ответом на эту необходимость.

Языковая политика Франции, неотделимая от формирования государственности, а впоследствии от идеи нации, долгое время опиралась на культивирование единства. Сегодня она должна быть переосмыслена и поставлена на службу разнообразия. 
- l'action d'aménagement, jusqu'ici opérée et prescrite par la France, via son Académie, sur la base de la variété française, se heurte à la mondialité de la langue. Il s'agit désormais de ratifier la variation, de concevoir une norme multiple, de mesurer la richesse du multiple. A cet égard la préparation, à l'initiative du Président Macron, d'un Dictionnaire des francophones, outil numérique cumulatif et participatif, préparé en partenariat francophone, rendant compte de la diversité mondiale du lexique francophone, est la version moderne de l'action traditionnelle de l'Etat en faveur de sa langue, dans un cadre théorique renouvelé.

- la protection de l'emploi a longtemps concerné la seule langue nationale. Les revendications régionalistes, les attitudes d'autres pays de l'Union européenne, la prise en compte du patrimoine immatériel et langagier ont conduit la France à reconsidérer son action en faveur des langues régionales et minoritaires. A cet égard, la création de la Délégation générale à la langue française et aux langues de France, premier organe de politique linguistique globale, est la réponse administrative moderne apportée à cet enjeu.

La politique linguistique de la France, indissociable de l'action de l'Etat puis de l'idée de Nation, a longtemps voué un culte à l'unité ; il lui importe maintenant de penser et de servir la diversité. 